\title{
Epidemiology of necrotizing enterocolitis
}

\author{
AM Kosloske \\ Departments of Surgery and Pediatrics, Ohio State University College of Medicine, and Children's Hospital, Columbus, OH, USA
}

\begin{abstract}
Kosloske AM. Epidemiology of necrotizing enterocolitis. Acta Pædiatr 1994;(suppl 396):2-7. Stockholm. ISSN 0803-5326

Necrotizing enterocolitis (NEC) is a worldwide problem that has emerged in the past 25 years as the most common gastrointestinal emergency in neonatal intensive care units (NICU). In the United States the incidence ranges from 1 to $7.7 \%$ of NICU admissions. Ninety percent of the patients are premature infants. Mucosal injury, bacterial colonization and formula feeding are the three major pathogenetic factors that have been documented in most infants who have developed NEC. However, NEC may develop only if a threshold of injury, imposed by the coincidence of at least two of three events (intestinal ischemia, pathogenic bacteria, and excess of protein substrate) is exceeded. Immunological immaturity of the gut in premature babies may represent the crucial risk factor. $\square$ Epidemiology, necrotizing enterocolitis, prematurity
\end{abstract}

AM Kosloske, Children's Hospital, 700 Children's Drive, Columbus, OH, USA

NEC is a worldwide problem, with heterogeneous scholars from fields of clinical and basic science. After 25 years, its pathogenesis and, more important, its prevention remain unclear. In the literature on NEC, anecdotal reports unfortunately outnumber the rigorous epidemiologic studies by a ratio of at least 100 to 1 . In the present publication, I discuss the epidemiology of NEC and overview its two main theories of pathogenesis: that of Santulli of New York (1) and that of Lawrence of Brisbane (2), with mention of my own (imperfect) attempts at a unifying hypothesis to explain outlying clinical phenomena $(3,4)$.

$\mathrm{NEC}$ has emerged in the past 25 years as the most common gastrointestinal emergency in the neonatal intensive care units (NICU) of many (but not all) countries of the world (5). It is a syndrome characterized by crepitant necrosis of the gut. Ninety percent of its victims are premature infants in the NICU, many of whom would have died in earlier times of respiratory complications. In the United States the incidence ranges from 1 to 3 cases per 1000 live births and $1-7.7 \%$ of NICU admissions. The mortality has been calculated at 13.1 deaths per 100000 live births, or $20-40 \%$ of cases (6). Clinically, NEC is characterized by the triad of abdominal distension, gastrointestinal bleeding, and pneumatosis intestinalis, i.e. air within the intestinal wall. In addition, infants with severe NEC may have air within the portal vein or pneumoperitoneum following intestinal perforation. In one study at the University of New Mexico, we correlated the roentgenographic findings with outcome of NEC, employing a grading system for the pneumatosis intestinalis as mild, moderate, or severe. The mortality was $18 \%, 21 \%$ and $62 \%$ respectively. The presence of portal venous gas at diagnosis of NEC was associated with a $65 \%$ mortality. Infants with a combination of severe pneumatosis and portal venous gas had the worst prognosis: a mortality of $86 \%$ (7). The outcome of NEC was thus predicted by the initial findings on $\mathrm{X}$-ray (Table 1).

\section{History}

Case reports of neonatal gastrointestinal perforations, by Siebold in 1825 (9) and by Genersich in 1891 (10), probably represent the first reported instances of NEC. Thelander's review in 1939 of the English, French, and German literature found 85 neonates with idiopathic gastrointestinal perforation; 84 of them died, some of whom probably had NEC (11). Colonic perforation after exchange transfusion was recognized in the $1950 \mathrm{~s}$ and amply documented before the clinical syndrome of NEC had evolved $(12,13)$.

The syndrome received its name after the report of Rossier in 1959, who described 15 infants, 14 of whom died, with "ulcerative-necrotic enterocolitis of the premature" (14). The clinical, radiographic, and pathologic entity of NEC was clearly described in the 1960s by Berdon, Touloukian, Santulli, and associates from the Babies Hospital in New York $(15,16)$, one of the first North American centers with an NICU. Since the 1970s, the proliferation of NICU has been accompanied by an increasing occurrence of $\mathrm{NEC}$, which has become the most common surgical emergency encountered in the neonate (17).

In 1975 Santulli attributed NEC to the interaction of three "essential components to the development of the disease": (1) injury to the intestinal mucosa, (2) the presence of bacteria, and (3) the availability of a 
Table 1. Radiographic abnormalities and clinical outcome in 147 infants with Stage II and Stage III (8) necrotizing enterocolitis (from Kosloske et al. (7)).

\begin{tabular}{|c|c|c|c|c|}
\hline $\begin{array}{l}\text { Radiographic } \\
\text { abnormality }\end{array}$ & $\begin{array}{l}\text { No. of } \\
\text { infants }\end{array}$ & $\begin{array}{l}\text { No. with } \\
\text { gangrene }\end{array}$ & $\begin{array}{c}\text { No. with } \\
\text { pan-necrosis }\end{array}$ & $\begin{array}{l}\text { No. of } \\
\text { deaths }\end{array}$ \\
\hline Pneumatosis, mild & $51(35)$ & $23(45)$ & $4(8)$ & $9(18)$ \\
\hline Pneumatosis, moderate & $57(39)$ & $32(56)$ & $7(12)$ & $12(21)$ \\
\hline Pneumatosis, severe & $32(22)$ & $29(91)$ & $18(58)$ & $20(62)$ \\
\hline Pneumoperitoneum & $45(31)$ & $45(100)$ & $15(33)$ & $21(47)$ \\
\hline Portal venous gas & $23(16)$ & $23(100)$ & $14(64)$ & $15(65)$ \\
\hline $\begin{array}{l}\text { Pneumatosis, severe, } \\
\text { and portal venous gas }\end{array}$ & $14(10)$ & $14(100)$ & $11(85)$ & $12(86)$ \\
\hline
\end{tabular}

Numbers in parentheses are percentages. The total number of infants is greater than 147 because some infants had two or three radiographic abnormalities. Six infants who survived and one who died had intestinal gangrene but no pneumatosis intestinalis. Pan-necrosis = necrosis involving $75 \%$ or more of total length of jejunum, ileum and colon.

metabolic substrate, i.e., formula feedings, in the gut lumen (1). These three elements could be documented or inferred in most premature infants who developed NEC by the mechanisms outlined below.

\section{Mucosal injury}

Intestinal ischemic injury is the result of decreased perfusion. A variety of events, e.g., vasoconstriction, hypotension, low flow, or thrombosis, may initiate the process. Mucosal injury is widely attributed to "the diving reflex", a mechanism of selective circulatory ischemia which occurs in response to asphyxia. Classical studies were performed by Scholander, a Scandinavian physiologist, who measured the cardiovascular reflexes of diving mammals and birds (18). His favorite experimental model was the laboratory seal, immersed in cool water. During a simulated dive, the seal's heart rate slowed from a normal of $80-90$ beats/ min to $5-6$ beats/min, with redistribution of blood flow to two organs: the heart and the brain. Peripheral arterial pressure decreased, and peripheral flow virtually ceased. When the seal surfaced, flow was restored to all the organs which had been ischemic, including the gut and the kidneys. Reactive hyperemia occurred. It is postulated that this reflex occurs in the premature infant whose gut is vulnerable to the ischemic insult, which initiates NEC. In 1969, Lloyd was the first to link the diving reflex to gastrointestinal perforations in the newborn, documenting a prior episode of asphyxia or shock in $80 \%$ of infants with perforations of the gastrointestinal tract (19).

Prenatal circulatory events may predispose to NEC. Malcolm and associates monitored flow velocity in the umbilical artery during high-risk pregnancies, and found an increased risk for NEC among fetuses with absent or reversed end diastolic flow velocity, $53 \%$ of whom developed NEC, compared to a $6 \%$ occurrence among matched controls (20).

Catheterization of the umbilical artery, an invasive yet common procedure for neonatal monitoring, may induce intestinal ischemia. Blanching or cyanosis of an infant's lower extremities is a frequent occurrence after advancement of the catheter tip into the abdominal aorta. Such blanching or cyanosis promptly resolves when the catheter is removed. Similar vasospastic phenomena may be inferred for the intestine, but may escape clinical detection unless NEC occurs. In a statistical study by Bunton and associates, catheterization of the umbilical artery was implicated as a predisposing factor for NEC (21), particularly with prolonged or complicated catheterization. Tyson and associates found severe catheter-related thromboatheromatous lesions at autopsy in 33 of 56 infants who had umbilical arterial catheters during life (22). Although major thrombosis of mesenteric arteries is rarely documented in NEC (23), small emboli from indwelling aortic catheters remain a risk, especially when the catheter tip is positioned above the orifices of the mesenteric arteries (24). Importance of catheter position remains controversial, however; an epidemiologic study by Kempley et al. of 308 infants whose umbilical arterial catheter had been randomly allocated to the "high" or "low" position showed no significant difference in risk of NEC between the two positions (11 cases of NEC in the "high" group; 9 in the "low" group) (25). Venous thromboemboli in the portal system have been implicated in cases of neonatal colonic perforation after exchange transfusion via an umbilical venous catheter $(12,13,26)$. In some instances, hyperviscosity might initiate thrombosis (27).

Congenital heart disease is associated with NEC. Three logical mechanisms are invoked: (1) lowered perfusion pressure in lesions with left ventricular outflow obstruction, e.g., coarctation of the aorta, (2) "diastolic steal" from retrograde blood flow into the aorta, which has been documented during diastole in infants with patent ductus arteriosus (PDA) (28), or (3) intestinal injury from injection of hyperosmolar contrast media during cardiac catheterization (29). These mechanisms have yet to be proven, however. In Leung's epidemiologic study of 22 risk factors among 
133 neonates with symptomatic congenital heart disease, there was no statistical link with left ventricular outflow obstruction, PDA, or cardiac catheterization (30).

\section{Bacteria}

Necrotizing enterocolitis occurs after birth, usually during the first or second week of life. A continuum may exist between intestinal atresia, which is the most common congenital anomaly of the gastrointestinal tract, and NEC, the most common neonatal emergency. In the sterile prenatal intestine, vascular insufficiency produces atresia. Postnatally, after the intestine is colonized with bacteria, the process is analogous to wet gangrene. Pathologic sections of late strictures of the intestine following NEC may bear a striking resemblance to sections from infants with atresia (31).

Bacterial colonization of the neonatal gut begins by contact with the vaginal flora and is propagated further by oral feedings and exposure to the environment. Normal infants are colonized with a range of aerobic and anaerobic flora by 10 days of age (32). In the aseptic conditions of the NICU, however, infants undergo delayed colonization with a limited number of bacterial species $(2,33)$, which tend to be virulent. Hoy, Millar and associates observed both a quantitative and qualitative change in the fecal flora prior to onset of NEC, with a decline in numbers of species and a shift to the Enterobacteriaceae $(34,35)$.

Although an infectious etiology has been suspected, no common microorganism is linked with NEC. The bacteria isolated are members of the normal flora of the neonatal gut, most commonly Klebsiella $(36,37) E$. coli $(36,38)$ and Clostridia $(39,40)$. Clostridium perfringens, which produces potent exotoxins, is associated with a fulminant, highly lethal form of NEC (41-44). Cases of NEC usually occur sporadically, but are sometimes clustered in an epidemic form. A recognized pathogen is occasionally isolated in such epidemics, e.g. Salmonella $(45)$, rotavirus $(46)$, coronavirus (47).

\section{Substrate}

Most infants who develop NEC were fed a cow's milk formula. Enteric bacteria, acting on formula as a substrate in the intestinal lumen, produce the blebs of pneumatosis intestinalis (48). Conversely, pneumatosis is found in only $57 \%$ of unfed infants who develop NEC (49). Some investigators who believe that overfeeding premature infants in order to meet their high caloric requirements may contribute to the development of NEC, advocate a restricted feeding schedule to decrease the incidence of $\operatorname{NEC}(50,51)$. Two prospective studies, however, showed no difference in the incidence of NEC between infants on a restrictive or rapidly increasing feeding schedule $(52,53)$. Formulas which are hyperosmolar may inflict direct injury to the mucosa $(54,55)$.

NEC is rare among infants fed breast milk alone. In the animal model of Barlow et al. (56), breast milk protected against NEC in newborn rats. In humans, breast milk plays a role in passive immunity of the neonatal intestine, and contains beneficial factors, including macrophages, secretory immunoglobulin $\mathrm{A}$, lactoferrin and other substances. The prospective multicenter study of Lucas and Cole showed that NEC was 6-10 times more common among formulafed babies than those fed breast milk alone, and three times more common in those who received formula plus breast milk, compared to those fed breast milk alone (57).

\section{The Lawrence hypothesis}

In 1982, Lawrence et al. (2) proposed an alternative hypothesis for pathogenesis for NEC, based on the aberrant colonization of NICU infants and on the vulnerability of the premature gut. These Australian investigators demonstrated delayed gut colonization with limited numbers and species of bacteria in the antiseptic NICU environment. They proposed that damage to the immature ileum, which absorbs bacterial toxins intact, initiated NEC. Their hypothesis was supported by Lawrence's model of necrotic enteritis in the germ-free neonatal rat, by introduction of toxinforming bacterial strains. The rat model, however, inexplicably ceased to work about one year later (58).

Epidemiologic studies have evaluated multiple predisposing factors, both maternal and neonatal, which were believed to be associated with NEC. Ryder et al. (59) carried out an exhaustive epidemiologic study from 13 different neonatal centers which evaluated 400 possible predisposing factors in 111 patients and 111 controls; 390 variables did not correlate with NEC. The 10 variables which appeared to correlate could have been the statistical result of chance alone. Stoll et al. $(60)$, working in a single center, studied 113 variables in 35 cases and 98 controls. None of the variables correlated with NEC. The only consistent finding, in $89 \%$ of cases, was prematurity. Such studies generally support the Lawrence hypothesis, which implicates a unique vulnerability of the premature intestine.

The immature intestine lacks secretory immunoglobulin A (IgA), which is important in the development of the mucosal barrier to invasion. Further, intestinal B and $T$ lymphocytes are decreased in number in the newborn infant (61). A study by Bell et al. showed increased serum levels of $\operatorname{IgA}$ in infants with $\mathrm{NEC}$, compared to a control group, (62), which might infer a decrease in secretory IgA at the mucosal border. Bauer et al. identified a decreased incidence of NEC among 
babies born after prenatal corticosteroid therapy to prevent RDS (63). Prevention of NEC has been reported by enhancement of the gastrointestinal host defense with human milk (57), immunoglobulin feeding (64), and corticosteroid administration (65).

\section{Threshold of injury}

Neither the Santulli theory nor the Lawrence hypothesis explains all cases of NEC. Ten percent of cases occur in term infants, usually considered at low risk for NEC. The syndrome may occur after the first two weeks of life, when gut colonization is usually complete (32) and the intestinal mucosa is no longer permeable to macromolecules (66). NEC has been reported in infants fed breast milk exclusively (67) and in infants who were never fed at all $(49,68)$. Most important, neither the theory of Santulli nor that of Lawrence addresses the question of why NEC has not developed in the majority of infants in the NICU, whose stress, environment, colonization, feedings and immaturity were no different from the $2-4 \%$ of infants in the NICU who developed the disease.

In an attempt to explain these phenomena, a unifying hypothesis derived from the Santulli theory was offered in 1984 as follows: NEC is caused by the coincidence of at least two of these three events: (1) intestinal ischemia, (2) colonization of the gut by pathogenic bacteria, and (3) excess protein substrate in the lumen. NEC is most likely to appear following quantitative extremes of these three elements, i.e. severe ischemia, highly pathogenic flora or a marked excess of substrate. NEC develops only if a threshold of injury sufficient to initiate intestinal necrosis is exceeded (3). The hypothesis was subsequently modified to consider the immunological immaturity of the premature gut (4). An experimental model was developed in germ-free and gnotobiotic rats for evaluation of the comparative effects of ischemia, bacteria, and substrate. In the pathogenesis of intestinal necrosis by this model, the most important of the three factors was bacteria (69). A mathematical model for NEC was subsequently proposed in an attempt to describe the contribution of various pathogenetic factors to ischemic bowel mass and mortality (70).

\section{Further epidemiologic considerations}

Although NEC is a serious neonatal problem in many countries in the world, its incidence is extremely low in Japan, Switzerland, and in some Scandinavian countries which have very low premature birth rates. Last week I scanned the contents of the last five years (1988-92) of Acta Padiatrica, published in Stockholm, for articles on NEC; none was found, compared to 22 articles and 3 letters to the editor during the last five years in the Journal of Pediatrics, published in St Louis, Missouri, USA. In Shimura's survey of 52 neontatal centers in Japan, only 89 cases of NEC were identified from 1985 to 1989 among 32790 admissions of infants under $2500 \mathrm{~g}(0.3 \%)(71)$. The Japanese incidence was thus $0.27 \%$, i.e., 4 to 28 times lower than that reported for the United States (6). In general, nations with low premature birth rates see very little NEC. Because epidemics of NEC occur, any epidemiologic investigations of NEC should employ simultaneous controls. Historical controls may yield deceptive data, i.e., an intervention which was introduced as an epidemic subsided could be credited with preventive powers, which, in fact, were false. And, sometimes, paradoxically, NEC seems to go away just as we are ready to begin the perfect prospective study in our nursery.

In conclusion, NEC is the most common gastrointestinal emergency in the NICU; however, the involved pathogenetic mechanisms as well as the appropriate preventive measures remain unclear. Epidemiologic studies are necessary to elucidate the responsible factors and mechanisms leading to $\mathrm{NEC}$, in order to pick up those premature babies who are at risk for developing this life threatening disease.

\section{References}

1. Santulli TV, Shullinger JN, Heird WC, Gongaware RD, Wigger J, Barlow B, et al. Acute necrotizing enterocolitis in infancy: a review of 64 cases. Pediatrics 1975;55:376-87

2. Lawrence G, Bates J, Gaul A. Pathogenesis of neonatal necrotizing enterocolitis. Lancet 1982;1:137-9

3. Kosloske AM. Pathogenesis and prevention of necrotizing enterocolitis: a hypothesis based on personal observation and a review of the literature. Pediatrics 1984;74:1086-92

4. Kosloske AM. A unifying hypothesis for pathogenesis and prevention of necrotizing enterocolitis. J Pediatr 1990;117:S56874

5. Kliegman RM, Fanaroff AA. Necrotizing enterocolitis. N Engl J Med 1984;310:1093-1103

6. Holman RC, Stehr-Green JK, Zelasky MT. Necrotizing enterocolitis mortality in the United States. Am J Publ Health 1989:79:987-9

7. Kosloske AM, Musemeche CA, Ball WS Jr, Ablin DS, Bhattacharyya $N$. Necrotizing enterocolitis: value of radiographic findings to predict outcome. AJR 1988;51:771-4

8. Bell MJ, Ternberg JL, Feigin RD. Neonatal necrotizing enterocolitis: therapeutic decisions based upon clinical staging. Ann Surg 1978;187:1-7

9. Siebold JF. Gerburtshulfe, frauenziemmer und Kinderkrankheiten. Heft I. Leipzig 1825;5:3

10. Genersich A. Bauchfellentzundung beim newgebornen in folge von perforation des ileums. Virchows Arch 1891;126:485

11. Thelander HE. Perforation of the gastrointestinal tract of the newborn infant. Am J Dis Child 1939;58:371-93

12. Corkery JJ, Dubowitz V, Lister J, et al. A colonic perforation after exchange transfusion. Br Med J 1968;4:345

13. Lucey JF. Colonic perforation after exchange transfusion. $N$ Engl J Med 1969;280:724

14. Rossier A, Sarrot S, Deplanque J. L'entcolite ulcero-necrotique du premature. Sem Hop Paris 1959;35:1428 
15. Berdon WE, Grossman H, Baker DH. Necrotizing enterocolitis in the premature infant. Radiology 1964;83:879-87

16. Touloukian RJ, Berdon WE, Amoury RA, Santulli TV. Surgical experience with necrotizing enterocolitis in the infant. J Pediatr Surg 1967;2:389-401

17. Kosloske AM. Necrotizing enterocolitis in the neonate. Surg Gynecol Obstet 1979;149:259-69

18. Scholander PF. The master switch of life. Sci Am 1963;209:92105

19. Lloyd JR. The etiology of gastrointestinal perforations in the newborn. J Pediatr Surg 1969;4:77-84

20. Malcolm G, Ellwood D, Devonald K, Beilby R, HendershotSmart D. Absent or reversed end diastolic flow velocity in the umbilical artery and necrotizing enterocolitis. Arch Dis Child $1991 ; 66: 805-7$

21. Bunton GL, Durbin GM, McIntosh N, Shaw DG, Taghizadeh A, Reynolds EOR, et al. Necrotizing enterocolitis: controlled study of three years' experience in a neonatal intensive care unit. Arch Dis Child 1977;52:772-7

22. Tyson JE, deSa DJ, Moore S. Thromboatheromatous complications of umbilical arterial catheterization in the newborn period. Arch Dis Child 1976;51:744-54

23. Joshi VV, Draper DA, Bates III RD. Neonatal necrotizing enterocolitis: occurrence secondary to thrombosis of abdominal aorta following umbilical arterial catheterization. Arch Pathol 1975:99:540

24. Lehmiller DJ, Kanto WP. Relationships of mesenteric thromboembolism, oral feedings and necrotizing enterocolitis. J Pediatr 1978;92:96

25. Kempley ST, Bennett S, Loftus BG, Cooper D, Gamsu HR. Randomized trial of umbilical arterial catheter position: clinical outcome. Acta Paediatr 1993;83:173-6

26. Touloukian RJ, Kadar A, Spencer RP. The gastrointestinal complications of neonatal umbilical venous exchange transfusion: a clinical and experimental study. Pediatrics 1973;51:3643

27. Hakanson DO, Oh W. Necrotizing enterocolitis and hyperviscosity in the newborn infant. J Pediatr 1977;90:461

28. Spach MS, Serwer GA, Anderson PAW, Canent RV, Levin AR. Pulsatile aortopulmonary pressure-flow dynamics of patent ductus arteriosus in patients with various hemodynamic states. Circulation 1980;61:110-22

29. Cooke RWI, Meradji M, Villeneuve YVD. Necrotizing enterocolits after cardiac catheterization in infants. Arch Dis Child 1980;55:66-8

30. Leung MP, Chau K, Hui P, Tam AYC, Chan FL, Lai C, Yeung C. Necrotizing enterocolitis in neonates with symptomatic congenital heart disease. J Pediatr 1988;12:1044-6

31. Kosloske AM, Martin LW. Surgical complications of necrotizing enterocolitis. Arch Surg 1973;107:223-8

32. Long SS, Swenson RM. Development of anaerobic fecal flora in healthy newborn infants. J Pediatr 1977;91:298-301

33. Goldman DA, LeClair J, Macone A. Bacterial colonization of neonates admitted to an intensive care environment. J Pediatr 1978;93:288-93

34. Hoy C, Millar MR, Mackay P, Goodwin PGR, Langdale V, Levene MI. Quantitative changes in faecal microflora preceding necrotizing enterocolitis. Arch Dis Child 1990;65:1057-9

35. Millar MR, MacKay P, Levenett, et al. Enterobacteriaceae and necrotizing enterocolitis. Arch Dis Child 1992;67:53-6

36. Bell MJ, Shackelford P, Feigin RD, Ternberg JL, Brotherton T. Epidemiologic and bacteriologic evaluation of neonatal necrotizing enterocolitis. J Pediatr Surf 1979;13:1-4

37. Guinan M, Schaberg D, Bruhn FW, Richardson J, Fox WW. Epidemic occurrence of neonatal necrotizing enterocolitis. Am J Dis Child 1979;133:594-7

38. Speer ME, Taber LH, Yow MD, et al. Fulminant neonatal sepsis and necrotizing enterocolitis associated with a "non-enteropathogenic" strain of Escherichia coli. J Pediatr 1976;89:91-5

39. Kliegman RM, Fanaroff AA, Izant R, Speck WT. Clostridia as pathogens in neonatal necrotizing enterocolitis. J Pediatr 1979;95:287-9

40. Kosloske AM, Ulrich JA. A bacteriologic basis for the clinical presentations of necrotizing enterocolitis. J Pediatr Surg 1980;15:558-64

41. Pedersen PV, Halveg AB, Hansen FH, Christiansen ED. Necrotizing enterocolitis - is it gas-gangrene of the bowel? Lancet 1976;2:715-6

42. Kosloske AM, Ulrich JA, Hoffman H. Fulminant necrotizing enterocolitis associated with clostridia. Lancet 1978;2:1014-6

43. Kosloske AM, Ball WS Jr, Umland E, Skipper B. Clostridial necrotizing enterocolitis. J Pediatr Surg 1985;20:155-9

44. Blakey JL, Lubitz L, Campbell NT, Gillam GL, Bishop RF, Barnes GL. Enteric colonization in sporadic neonatal necrotizing enterocolitis. $\mathbf{J}$ Pediatr Gastroenterol Nutrit 1985;4:591-5

45. Stein H, Beck J, Solomon A, Schmaman A. Gastroenteritis with necrotizing enterocolitis in premature babies. $\mathrm{Br}$ Med J 1972;2:616

46. Rotbart HA, Levin MJ, Yolken RH, Manchester DK, Jantzen J. An outbreak of rotavirus-associated neonatal necrotizing enterocolitis. J Pediatr 1983;103:454-9

47. Chany C, Moscovici O, Lebon P, Rousset S. Association of coronavirus infection with neonatal necrotizing enterocolitis. Pediatrics 1982;69:209-14

48. Engel RR, Virnig NW, Hunt CE, Levitt MD. Origin of mural gas in necrotizing enterocolitis. Pediatr Res 1973;7:292

49. Marchildon MB, Buck BE, Abdenour G. Necrotizing enterocolitis in the unfed infant. J Pediatr Surg 1982;17:620-4

50. Brown EG, Sweet AY. Preventing necrotizing enterocolitis in neonates. JAMA 1978;240:2452-4

51. Goldman HI. Feeding and necrotizing enterocolitis. Am J Dis Child 1980;134:553-5

52. Book LS, Herbst JJ, Jung AL. Comparison of fast-and-slow feeding rate schedules to the development of necrotizing enterocolitis. J Pediatr 1976;89:463-6

53. LaGamma EF, Ostertag SG, Birenbaum H. Failure of delayed oral feedings to prevent necrotizing enterocolitis. Results of study in very low birth weight neonates. Am J Dis Child 1985;139: 385-9

54. Book LS, Herbst JJ, Atherton SO, Jung AL. Necrotizing enterocolitis in low-birth-weight infants fed an elemental formula. J Pediatr 1975;87:602-5

55. De Lemos RA, Rogers JH Jr, McLaughlin W. Experimental production of necrotizing enterocolitis in newborn goats. Pediatr Res 1974;8:380

56. Barlow B, Santulli TV, Heird WC, Pitt J, Blanc WA, Schullinger JN. An experimental study of acute necrotizing enterocolitis: the importance of breast milk. J Pediatr Surg 1974;9:587-95

57. Lucas, A, Cole TJ. Breast milk and neonatal necrotizing enterocolitis. Lancet 1990;336:1519-23

58. Lawrence GW, Bates J. Pathogenesis of neonatal necrotizing enterocolitis. Lancet 1983;1:540

59. Ryder RW, Sheiton JD, Guinan ME. Necrotizing enterocolitis: a prospective multicenter investigation. Am $J$ Epidemiol $1980 ; 112: 113-23$

60. Stoll BJ, Kanto WP, Glass RI, Nahmias AJ, Brann AW Epidemiology of necrotizing enterocolitis: a case control study. J Pediatr 1980;96:447-51

61. Udall JN Jr. Gastrointestinal host defense and necrotizing enterocolitis: an update. J Pediatr 1990;117:S33-43

62. Bell MJ, Shackelford P, Molleston J. Hypothesis: neonatal necrotizing enterocolitis is caused by acquisition of a pathogenic organism by a susceptible host infant. Surgery 1985;97: 350-3

63. Bauer CR, Morrison JC, Poole KW, Korones SB, Boehm JJ, Rigatto $\mathrm{H}$, Zachman RD. A decreased incidence of necrotizing enterocolitis after prenatal glucocorticoid therapy. Pediatrics 1984;73:682

64. Eibl MM, Wolf HM, Furnkranz H, Rosenkranz A. Prevention of 
necrotizing enterocolitis in low-birth-weight infants by IgA-IgG feeding. N Engl J Med 1988;319:1-7

65. Halac E, Halac J, Begue EF, Casanas JM, Indiveri DR, Petit JF, Figureora MJ, Olmas JM, Rodriguez LA, Obregon RJ. Prenatal and postnatal corticosteroid therapy to prevent neonatal necrotizing enterocolitis: a controlled trial. J Pediatr 1990;117: 132-8

66. Walker WA. Gastrointestinal host defense: importance of gut closure in control of macromolecular transport. Ciba Foundation Symposium 1979;70:201-19

67. Kliegman RM, Pittard WB, Fanaroff AA. Necrotizing enterocolitis in neonates fed human milk. J Pediatr 1979;95:450-3
68. Wilson R, Kanto WP Jr, McCarthy BJ, Feldman RA. Age at onset of necrotizing enterocolitis: risk factors in small infants. Am J Dis Child 1982;136:814-6

69. Musemeche CA, Kosloske AM, Bartow SA, Umland ET Comparative effects of ischemia, bacteria and substrate on the pathogenesis of intestinal necrosis. J Pediatr Surg 1986;21: 536-7

70. Kosloske AM. A mathematical model for necrotizing enterocolitis. Presented at the Festschrift honoring Lester W. Martin, MD, Cincinnati, Ohio, September 27, 1990

71. Shimura K. Necrotizing enterocolitis? A Japanese survey. NICU 1990:3:5-7 